\title{
$\mathcal{G}^{\mathcal{B}}$
}

\section{FOREIGN SOVEREIGN IMMUNITY AND DOMESTIC OFFICER SUITS}

\author{
Curtis A. Bradley \& Jack L. Goldsmith
}

W

E RECENTLY ARGUED in these pages that international law treats official-capacity suits brought against a foreign state's officers as suits against the state itself and thus as subject to the state's immunity, even in suits alleging human rights abuses. ${ }^{1}$ This immunity regime under international law differs from the immunity regime that applies in the United States in suits brought against state and federal officials for violations of federal law. Despite the federal government's sovereign immunity and the immunity of state governments under Eleventh Amendment jurisprudence, courts often allow suits against federal and state officers for their official actions. While these officers can invoke individual immunity doctrines, typically qualified immunity, the overall immunity available in domestic officer suits is narrower than the immunity available under international law for suits against foreign officers.

As best we can tell, no one has ever explained why the immunity rules that apply to suits against foreign officials under interna-

Curtis Bradley is the Richard A. Horvitz Professor at Duke Law School. Jack Goldsmith is the Henry L. Shattuck Professor at Harvard Law School.

1 See Curtis A. Bradley \& Jack L. Goldsmith, Foreign Sovereign Immunity, Individual Officials, and Human Rights Litigation, 13 GREEN BAG 2D 9, 15-16, 19-22 (2009). 


\section{Curtis A. Bradley \& Jack L. Goldsmith}

tional law differ from the immunity rules that apply to suits against domestic officials under U.S. domestic law. This essay attempts to provide such an explanation. We begin by showing that the differential treatment of foreign and domestic officer suits has deep roots in British and American common law. We then show that Congress has not acted to alter this common law backdrop, and we explain the significance of this fact. Finally, we discuss functional reasons for the long-time differential treatment of suits against domestic and foreign officials.

\section{DOMESTIC OfFicer SUITS AT COMMON LAW}

E xcept to the extent they have voluntarily waived it, both the federal government and the state governments in the United States have broad immunity from suit in U.S. courts. ${ }^{2}$ Notwithstanding this immunity, courts have long allowed suits to be brought against federal and state officials for acts carried out on behalf of the government.

Such domestic officer suits can be traced to the British common law, which, despite maintaining that "the King can do no wrong," allowed suits against government officers, as well as certain "petitions of right" directly against the Crown. ${ }^{3}$ Under this regime, the Crown's immunity "did not extend to ministers and Crown officers, who were liable personally in law for anything unlawful that they did; and it made no difference that they were acting in an official capacity."

2 On the immunity of the federal government, see, for example, FDIC v. Meyer, 510 U.S. 471, 475 (1994), and United States v. Sherwood, 312 U.S. 584, 586 (1941). On the immunity of state governments, see, for example, Alden v. Maine, 527 U.S. 706 (1999), and Hans v. Louisiana, 134 U.S. 1 (1890).

3 See generally Louis L. Jaffe, Suits Against Governments and Officers: Sovereign Immunity, 77 Harv. L. Rev. 1 (1963); Guy I. Seidman, The Origins of Accountability: Everything I Know About the Sovereign's Immunity, I Learned from King Henry III, 49 ST. LOUIS U.L.J. 393 (2005).

${ }^{4}$ William Wade, The Crown, Ministers and Officials: Legal Status and Liability, in THE Nature of the Crown: A Legal and Political Analysis 25-26 (Maurice Sunkin \& Sebastian Payne eds., 1999). 


\section{Sovereign Immunity \& Domestic Officer Suits}

The approach of the United States to officer immunity has, with modifications due to its federal system, been essentially the same. A classic example is the Supreme Court's 1804 decision in Little v. Barreme. In that case, a navy captain exceeded his statutory authority in seizing a vessel during the Quasi-War with France, and the Court held that he could be sued for damages. The Court reached this conclusion even though the captain had acted pursuant to instructions from the President, reasoning that "the instructions cannot change the nature of the transaction, or legalize an act which without those instructions would have been a plain trespass."

As the Court would later explain, the basic idea behind allowing officer suits was that "[a]ll the officers of the government, from the highest to the lowest, are creatures of the law, and are bound to obey it." For much of the nineteenth century, the Court granted sovereign immunity to state and federal governments for alleged violations of the common law if they were named as a party of record, but denied immunity to state and federal officials regardless of whether they acted in an official capacity. ${ }^{7}$ The Supreme Court eventually retreated from this approach and in some cases began to look behind the complaint to determine if the government was the real party in interest, especially in cases that did not involve tort claims. ${ }^{8}$ Even with this shift, however, the Court "left in place a broad scope for suits against officers, as long as it could be shown that the officer had personally committed an actionable wrong."

In the early twentieth century, the Supreme Court expanded the permissible scope of officer suits to include constitutional claims in addition to common law claims. In Ex parte Young, it permitted a suit for injunctive relief against a state attorney general for violating the Fourteenth Amendment in enforcing allegedly confiscatory rail-

${ }^{5} 6$ U.S. (2 Cranch) 170, 179 (1804).

${ }^{6}$ United States v. Lee, 106 U.S. 196, 220 (1882).

7 See, e.g., Davis v. Gray, 83 U.S. 203, 220 (1872); Osborn v. Bank of the United States, 22 U.S. (9 Wheat.) 738, 857 (1824).

8 See, e.g., In re Ayers, 123 U.S. 443, 487-88 (1887).

9 Richard H. Fallon, JR. et al., Hart \& Wechsler's The Federal Courts and THE FEDERAL SySTEM 853 (6th ed. 2009). 


\section{Curtis A. Bradley \& Jack L. Goldsmith}

road rates on behalf of the state. ${ }^{10}$ The reasoning underlying the $E_{x}$ parte Young doctrine is that when an official, even in an official capacity, acts contrary to the "superior authority" of the federal Constitution, the official is "stripped of his official or representative character and is subjected in his person to the consequences of his individual conduct." ${ }^{11}$ Some commentators have described this reasoning as a "fiction," since it envisions that an official can simultaneously engage in state action for purpose of constitutional liability but act in a personal capacity for purposes of immunity. ${ }^{12}$ As the Supreme Court has explained, however, the Ex parte Young rule "has been accepted as necessary to permit the federal courts to vindicate federal rights and hold state officials responsible to 'the supreme authority of the United States.'”13

Ex parte Young applies only to suits for prospective relief. The rules for suits against officials for monetary damages are more complex. The Supreme Court has held that sovereign immunity applies in damages suits brought against state officers in their "official" capacity, but not when the suit is brought against the officers in their "personal" capacity. ${ }^{14}$ Importantly, in distinguishing between official and personal capacity suits, the Court has, at least in tort cases, allowed plaintiffs to decide how the case should be characterized: if the plaintiff pleads against an official in their personal capacity, the court will accept that characterization, but the plaintiff will be allowed to seek damages only from the official, not the state. ${ }^{15}$ Therefore, the bottom line in damages suits, just as with injunctive relief

${ }^{10} 209$ U.S. 123 (1908).

${ }^{11}$ Id. at 160 .

${ }^{12}$ See, e.g., Charles Alan Wright \& Mary Kay Kane, LaW of Federal Courts 311 (6th ed. 2002); Kenneth Culp Davis, Suing the Government by Falsely Pretending to Sue an Officer, 29 U. CHI. L. Rev. 435, 437 (1962). But see John Harrison, Ex parte Young, 60 StAn. L. ReV. 989 (2008).

${ }^{13}$ Pennhurst State School \& Hospital v. Halderman, 465 U.S. 89, 105 (1984).

${ }^{14}$ See Hafer v. Melo, 502 U.S. 21, 27 (1991).

${ }^{15}$ See id. This is true even if it is the state's policy to indemnify the official. See generally John C. Jeffries, Jr., In Praise of the Eleventh Amendment and Section 1983, 84 VA. L. REV. 47 (1998). 


\section{Sovereign Immunity \& Domestic Officer Suits}

under Ex parte Young, is that plaintiffs can plead around state sovereign immunity by suing state officials rather than the state itself. ${ }^{16} \mathrm{~A}$ similar regime applies to suits against federal officials for constitutional violations. ${ }^{17}$

Although federal and state officials are often unable to invoke the immunity of the government itself, they are allowed to invoke individual immunity doctrines. Most relevant for present purposes, officials carrying out executive and administrative functions are generally entitled to qualified immunity. This immunity shields them from damages claims unless it is shown that they violated "clearly established" federal rights "of which a reasonable person would have known."

\section{FOREIGN OfFICER SUITS AT COMMON LAW}

U nlike the common law immunity regime applicable to domestic officials, at common law in both Great Britain and the United States, suits against foreign officials for their official acts were considered suits against the foreign state and thus were subject to the state's immunity.

Referring to "principles of English law which are so well known that I refrain from citing authority," an eminent British judge explained in 1964 that "[a] foreign sovereign government . . . can act only through agents, and the immunity to which it is entitled in respect of its acts would be illusory unless it extended also to its agents in respect of acts done by them on its behalf." ${ }^{19}$ Nearly a cen-

${ }^{16}$ Plaintiffs appear to have less leeway in avoiding sovereign immunity when bringing contract-oriented claims. See, e.g., Edelman v. Jordan, 415 U.S. 651, 665 (1974); Ford Motor Co. v. Dept. of Treasury, 323 U.S. 459, 463 (1945).

${ }^{17}$ See Gregory C. Sisk, Litigation with the Federal Government 89 (4th ed. 2006). For state law claims, however, the Westfall Act provides federal officials with broader immunity than state officials. See 28 U.S.C. § 2679(d).

${ }^{18}$ See, e.g., Wilson v. Layne, 526 U.S. 603, 609 (1999); Harlow v. Fitzgerald, 457 U.S. 800, 818 (1982). This immunity did not develop in the common law until late in the nineteenth century. See HART \& WeCHSLER, supra note 9, at 996. In earlier cases, such as Little v. Barreme, good faith was not a defense.

${ }^{19}$ Zoernsch v. Waldock [1964] 1 WLR 675, 692 (C.A.). 


\section{Curtis A. Bradley \& Jack L. Goldsmith}

tury earlier, a British court dismissed a suit against agents of Peru who had issued Peruvian government bonds, reasoning: "You cannot sue the Peruvian Government . . . and it would be a monstrous usurpation of jurisdiction to endeavour to sue a foreign government indirectly, by making agents in this country defendants." ${ }^{20}$

The same rule prevailed in the United States. An early recognition of the rule came in a 1794 opinion of Attorney General William Bradford concerning a state court prosecution of the former Governor of French Guadaloupe for condemning an American vessel during his time in office. Bradford reasoned: "if the seizure of the vessel is admitted to have been an official act, done by the defendant by virtue, or under color, of the powers vested in him as governor, that it will of itself be a sufficient answer to the plaintiff's action." ${ }^{21}$

Four years later, Attorney General Charles Lee, commenting on a civil suit against a British agent, similarly proclaimed: "it is as well settled in the United States as in Great Britain, that a person acting under a commission from the sovereign of a foreign nation is not amenable for what he does in pursuance of his commission, to any judiciary tribunal in the United States."22 Citing these and other examples, the Second Circuit declared a century later that "[t]he law officers of the United States have uniformly advised the executive

${ }^{20}$ Twycross v. Dreyfus, (1877) 5 Ch. D. 605, 618 (James, L.J.). See also Jones v. Ministry of the Interior of the Kingdom of Saudi Arabia [2006] UKHL 26, para. 10, [2007] 1 A.C. 270 (Bingham, L.J.) (citing "wealth of authority" for the proposition that "[t]he foreign state's right to immunity cannot be circumvented by suing its servants or agents").

${ }^{21}$ Suits Against Foreigners, 1 Op. Atty Gen. 45, 46 (1794). Before Erie R.R. Co. v. Tompkins, 304 U.S. 64 (1938), immunity for foreign officials had the status in the United States of general common law rather than federal law. Probably for this reason, Attorney General Bradford disclaimed the authority to interfere in the state court proceedings, although the plaintiff nevertheless discontinued the case after the issuance of Bradford's opinion. See Waters v. Collot, 2 U.S. (2 Dall.) $247,248 \mathrm{n} . *(1796)$.

${ }^{22} 1$ Op. Atty Gen. 81 (1797). Following Attorney General Bradford's 1794 opinion, Attorney General Lee disclaimed authority to interfere in the state court proceeding. 


\section{Sovereign Immunity \& Domestic Officer Suits}

department that individuals are not answerable in foreign tribunals for acts done in their own country, in behalf of their government, by virtue of their official authority." 23

The famous Caroline incident of 1837 implicated a similar principle. The Caroline was an American steamboat that British troops destroyed in American waters after it had been seen carrying arms to Canadian rebels. Three years later, New York state officials arrested Alexander McLeod, a British citizen, and charged him with murder and arson in connection with the incident. The British Foreign Minister objected to the indictment on the ground that McLeod was immune from prosecution because he was a British official who had carried out a public function on Britain's behalf. ${ }^{24}$ Importantly, Secretary of State Daniel Webster agreed with this contention. He stated: "The Government of The United States entertains no doubt that, after this avowal of the transaction, as a public transaction, authorized and undertaken by the British authorities, individuals concerned in it ought not, by the principles of public law, and the general usage of civilized States, to be holden personally responsible in the ordinary tribunals of law, for their participation in it." 25

The Supreme Court's late nineteenth-century decision in Underhill v. Hernandez also endorsed the immunity of foreign officials for their official acts. ${ }^{26}$ In Underhill, a U.S. citizen sued a Venezuelan military commander, whose revolutionary government had been recognized by the United States, for unlawful assault and detention in Venezuela. The decision is most famous for its articulation of the act of state doctrine, pursuant to which "the courts of one country will not sit in judgment on the acts of the government of another

\footnotetext{
${ }^{23}$ Underhill v. Hernandez, 65 F. 577, 580 (2d Cir. 1895), affd on other grounds, 168 U.S. 250 (1897) .

${ }^{24}$ See Letter from Mr. Fox to Mr. Webster (Mar. 12, 1841), reprinted in 29 BRITISH AND FOREIGN STATE PAPERS, 1840-1841, at 1127 (1857).

${ }^{25}$ Id. at 1131 (Letter from Mr. Webster to Mr. Fox (Apr. 24, 1841)). Like his predecessors, see supra notes 21, 22, Webster disclaimed authority to interfere with the ongoing state court proceedings. Id. at 1132 .

${ }^{26} 168$ U.S. at 252.
} 
done within its own territory." The Supreme Court also recognized, however, "[t]he immunity of individuals from suits brought in foreign tribunals for acts done within their own States, in the exercise of governmental authority, whether as civil officers or as military commanders. ${ }^{27}$ Similarly, the lower court in that case noted that, "because the acts of the official representatives of the state are those of the state itself, when exercised within the scope of their delegated powers, courts and publicists have recognized the immunity of public agents from suits brought in foreign tribunals for acts done within their own states in the exercise of the sovereignty thereof." 28

In several cases in the twentieth century, U.S. courts acknowledged the same principle. In Lyders v. Lund, a 1929 decision in a suit to recover lawyer's fees and expenses from a consul of Denmark, the court noted that "in actions against the officials of a foreign state not clothed with diplomatic immunity, it can be said that suits based upon official, authorized acts, performed within the scope of their duties on behalf of the foreign state, and for which the foreign state will have to respond directly or indirectly in the event of a judgment, are actions against the foreign state." ${ }^{29}$ Similarly, in Heaney $v$. Government of Spain, a case involving a contract claim brought against a Spanish consul, the Second Circuit stated that the immunity of a foreign state extends to any "'official or agent of the state with respect to acts performed in his official capacity if the effect of exercising jurisdiction would be to enforce a rule of law against the state. " 30 The court in Heaney quoted for this proposition a provision in the Restatement (Second) of Foreign Relations Law, published in 1965, which purported to summarize the common law up to that point. ${ }^{31}$

${ }^{27} \mathrm{Id}$.

${ }^{28} 65$ F. at 579 .

${ }^{29} 32$ F.2d 308, 309 (N.D. Cal. 1929). The court also noted that the private or unauthorized acts of such officials would not warrant immunity, and outlined the process whereby the consul could make a showing that his acts were in fact official.

${ }^{30} 445$ F. 2d 501, 504 (2d Cir. 1971).

${ }^{31}$ See Restatement (Second) of the Foreign Relations Law of the United 


\section{Sovereign Immunity \& Domestic Officer Suits}

\section{CONGRESS AND THE COMMON LAW}

$\mathrm{T}$ he common law's differential treatment of immunity in suits against domestic officials and immunity in suits against foreign officials is of course subject to alteration by Congress. The next question, therefore, is whether Congress has done anything to alter this common law backdrop. In analyzing this question, an important canon of construction is that legislation in an area governed by the common law is ordinarily construed so that it does not override the common law absent some clear indication of congressional intent to do so. $^{32}$

As we explained in our previous essay, the most relevant jurisdictional statute in suits against foreign officials is the 1976 Foreign Sovereign Immunities Act (FSIA), which establishes a presumption of immunity in suits against states, subject to specific statutory exceptions. ${ }^{33}$ We argued in that essay that the FSIA's immunity for states should be construed to extend to state officers who act in an official capacity. Even if one does not accept that construction of the FSIA, however, foreign officer immunity should continue to be available as a matter of common law, since there is no indication in the FSIA's text or legislative history that Congress intended to abrogate this common law immunity. ${ }^{34}$

The presumption against statutory derogation of common law immunities is not only relevant to jurisdictional statutes like the

STATES $\S 66$ (1965). See also Bradford v. Director General of Railroads of Mexico, 278 S.W. 251 (Tex. 1925) (treating contract suit brought against a Mexican official as a suit against Mexico and thus as subject to Mexico's sovereign immunity).

${ }^{32}$ See Bradley \& Goldsmith, supra note 1, at 14.

${ }^{33}$ See 28 U.S.C. $\S \S 1604,1605$.

${ }^{34}$ See Bradley \& Goldsmith, supra note 1, at 14. Courts applying a common law of immunity in ATS cases would do so pursuant to the common law authority that the Supreme Court in Sosa v. Alvarez-Machain, 542 U.S. 692 (2004), found implicit in the ATS. More broadly, courts would be required to develop any common law immunity rules in a manner consistent with the political branches' policy choices, including choices reflected in the FSIA. See Curtis A. Bradley \& Jack L. Goldsmith, Pinochet and International Human Rights Litigation, $97 \mathrm{MICH}$. L. REV. 2129, 2160-67 (1999). 
FSIA. It is also relevant to causes of action, where the Court has gone so far as to "presume[] that Congress intended to incorporate well-established common law rules that were in operation at the time the statutes were passed into the causes of action created by the statutes." ${ }^{35}$ For example, courts have construed the cause of action statute most frequently invoked in domestic officer litigation 42 U.S.C. $\S 1983$ - to be subject to common law immunity defenses. As the Supreme Court has explained, Section 1983 has been construed to be "in harmony with general principles of tort immunities and defenses rather than in derogation of them."

The principal statutory basis for human rights litigation against foreign officials is the Alien Tort Statute (ATS). Arguments in favor of preserving the common law immunity regime are even stronger under the ATS than under Section 1983. The ATS has not been substantively modified since it was first enacted as part of the Judiciary Act of 1789. Nothing in the text of the statute or in the timing of its enactment indicates that Congress in any way limited common law immunity. Moreover, the Supreme Court made clear in Sosa v. Alvarez-Machain that the ATS, unlike Section 1983, is a jurisdictional statute that does not itself confer a cause of action, and that ATS claims result from federal courts' "residual common law discretion." ${ }^{37}$ The presumption that a cause of action does not abrogate common law immunity should be at least as powerful when the cause of action is itself fashioned from the common law. ${ }^{38}$ Indeed, the central reason why the Court in Sosa permitted a "modest number" of modern international law claims under the ATS was to pre-

${ }^{35}$ Jack M. Beermann, Common Law Elements of the Section 1983 Action, 72 CHI.-KeNT L. REV. 695, 698 (1997).

${ }^{36}$ Imbler v. Pachtman, 424 U.S. 409, 418 (1976).

${ }^{37} 542$ U.S. 692, 712, 738 (2004).

${ }^{38}$ Another statute relevant to human rights litigation - the Torture Victim Protection Act (TVPA) - does provide a cause of action for certain claims of torture and extrajudicial killing committed "under actual or apparent authority, or color of law, of any foreign nation.” 28 U.S.C. $\$ 1350$ note. The TVPA does not mention immunity, much less limit it, and the legislative history disavows any intent to affect immunity. See Bradley \& Goldsmith, supra note 1, at 20. 


\section{Sovereign Immunity \& Domestic Officer Suits}

serve the historic common law backdrop against which the ATS was enacted, pursuant to which a handful of international law claims could have been brought against private actors without the need for a statutory cause of action. ${ }^{39}$ This common law backdrop includes common law immunity rules.

\section{FUNCTIONAL CONSIDERATIONS}

$\mathrm{W}$

e now consider the functional justifications that might explain why the immunity regime for suits against foreign officials is so different than the one that applies to suits against domestic officials. Because the immunity issue arises most frequently when executive officials are sued, we will focus on the contrast between the qualified immunity that domestic executive officials receive for their official acts and what is in effect an absolute immunity accorded to foreign officials for their official acts.

The qualified immunity doctrine that has been developed in domestic cases "is the result of the balancing of 'fundamentally antagonistic social policies. " $\$ 0$ Allowing civil damages for government wrongdoing vindicates federal law, compensates victims, deters future misconduct, and spreads the risk of government harm among all taxpayers. ${ }^{41}$ Immunity from suit, by contrast, promotes vigorous public decisionmaking and allows officials to concentrate on their public duties without fear of harassing litigation. ${ }^{42}$ As noted above, the Supreme Court has balanced these social policies for U.S. officials by conferring immunity on those officers who do not violate clearly established law of which a reasonable person would have known.

At first glance, and setting doctrine and historical practice aside for a moment, it might seem that the functions served by civil dam-

${ }^{39} 542$ U.S. at 724.

${ }^{40}$ United States v. Stanley, 483 U.S. 669, 695 n.13 (1987) (Brennan, J., concurring) (quoting Barr v. Mateo, 360 U.S. 564, 576 (1959) (plurality opinion)).

${ }^{41}$ See, e.g., Owen v. Independence, 445 U.S. 622, 655 \& n.39 (1980) (riskspreading and law vindication); Robertson v. Wegmann, 436 U.S. 584, 590-91 (1978) (compensation and deterrence).

${ }^{42}$ See, e.g., Anderson v. Creighton, 483 U.S. 635, 638 (1987). 


\section{Curtis A. Bradley \& Jack L. Goldsmith}

ages (subject to qualified immunity) in domestic officer suits also apply to human rights cases against foreign officials. After all, the award of civil damages in ATS cases against foreign officials can be seen as vindicating international law and serving the same functions of compensation, deterrence, and risk-spreading goals as liability for domestic officers. Nonetheless, there are discontinuities between domestic and foreign officer suits that help to explain the difference between domestic and foreign officer immunity rules.

In the domestic context, there is a debate about whether the judiciary should be attempting to balance the complicated domestic social tradeoffs necessary to develop an optimal liability/immunity regime. ${ }^{43}$ Regardless of how that debate is resolved, U.S. courts face substantially greater challenges in identifying and resolving these social tradeoffs for other countries. Foreign nations have different legal and political cultures, different attitudes toward spreading risk through civil damages, and different degrees of wealth (and thus different capacities to pay civil damages). Courts would need to take account of these and other factors to adequately balance the "fundamentally antagonistic social policies" relevant to designing a liability/immunity regime. It is doubtful, however, that they have either the necessary information or expertise to engage in this exercise, and it is almost certain that such an exercise would be perceived by other nations as illegitimate.

One way to appreciate this point is to consider the foreign fiscal consequences of civil liability for foreign officials in U.S. courts. ${ }^{44}$ Just as state and federal governments often feel compelled to indemnify officials for damages assessed in civil cases arising from their official acts, ${ }^{45}$ so too foreign countries will often feel compelled to indemnify their officials for any damages awarded in another nation's court. If a U.S. court awards civil damages against a

${ }^{43}$ See, e.g., Crawford-El v. Britton, 523 U.S. 574, 611-12 (1998) (Scalia, J., dissenting).

${ }^{44}$ We thank John Harrison for this insight. One limitation on this point is that, on average, it will likely be more difficult to enforce monetary judgments against foreign officials than against domestic officials.

${ }^{45}$ See Jeffries, supra note 15 , at 50 . 


\section{Sovereign Immunity \& Domestic Officer Suits}

foreign official, it would (in those cases where the foreign state feels compelled to indemnify) effectively require the expenditure of foreign public funds that the foreign state might think are better spent on other public goals in that country (including goals related to the alleged human rights abuses in question, such as community rebuilding and development). Foreign nations understandably do not trust U.S. courts to manage their public administration and fiscal matters, especially since (unlike in the purely domestic officer suit) the costs of mistaken overcompensation by the U.S. courts are not borne by the United States political community but rather are borne by the foreign community, which must spend money in ways contrary to its wishes.

Unlike in the domestic realm, a qualified immunity regime in foreign officer cases would not adequately address these concerns. The Supreme Court does not play the same role in ATS suits against foreign officers, which typically allege violations of international law rights, that it plays in domestic officer cases, which typically allege constitutional violations. The Supreme Court is the definitive interpreter of what counts as "clearly established" constitutional law in its qualified immunity decisions, and these decisions have a high degree of legitimacy within the U.S. system. By contrast, the Supreme Court is one of hundreds of non-definitive interpreters around the globe of what counts as "clearly established" international law. Moreover, in contrast to its constitutional law interpretations, its interpretations of international law are often viewed around the world as idiosyncratic. In particular, the practice of some lower courts in the United States of imposing civil liability for alleged human rights abuses committed abroad is viewed outside the United States as illegitimate and indeed as contrary to international law. ${ }^{46}$ In short, the notion of "clearly established law" makes much less sense in the typical foreign officer suit than in the typical domestic officer suit. ${ }^{47}$

\footnotetext{
${ }^{46}$ See Bradley \& Goldsmith, supra note 1, at 22-23.

${ }^{47}$ Cf. Belhas v. Ya'alon, 515 F.3d 1279, 1292 (D.C. Cir. 2008) (Williams, J., concurring) (rejecting argument that foreign officials should be denied immunity for egregious human rights violations because, under that approach, "immunity
} 


\section{Curtis A. Bradley \& Jack L. Goldsmith}

One might argue that these considerations do not matter, and that the central consideration should be the vindication of international law, just as civil liability in the domestic realm is thought necessary to vindicate constitutional law. It is important to keep in mind, however, that there are numerous methods of accountability besides civil liability in foreign courts for alleged human rights abuses by government officials, including civil or criminal liability in the home country, or one of a variety of international criminal courts. In addition, the difficulty of translating the "vindication of law" argument to the foreign officer context becomes apparent when one considers the remedy of injunctions. This remedy, a central vehicle for vindicating constitutional rights in domestic officer suits, is assumed not to be available in suits concerning violations of international human rights law by foreign officials - and, indeed, we are not aware of a single ATS decision that has awarded such relief.

This leads to the final and in some sense most fundamental functional difference between domestic and foreign officer suits: the overlay of foreign relations considerations that apply to the latter. Because of the factors already mentioned, foreign officer suits in U.S. courts are controversial, and threaten international discord. ${ }^{48}$ Numerous foreign relations law doctrines, such as the act of state doctrine, the presumption against extraterritoriality, and the rule of non-inquiry in extradition cases are designed to ensure, on separation of powers grounds, that unelected and unaccountable courts do not inadvertently, or without clear political branch guidance, pursue a course of action in litigation that threatens international discord. ${ }^{49}$ The Supreme Court in Sosa relied on precisely these factors

could be determined only at the moment of resolution on the merits, at which point it would commonly be irrelevant").

${ }^{48}$ See, e.g., John B. Bellinger III, Enforcing Human Rights in U.S. Courts and Abroad: The Alien Tort Statute and Other Approaches, 42 VAnd. J. Transnat'L L. 1, 9 (2009); see also Belhas, 515 F.3d at 1291 (Williams, J., concurring).

${ }^{49}$ See, e.g., Banco Nacional de Cuba v. Sabbatino, 376 U.S. 398, 423 (1964) (act of state doctrine); Equal Employment Opportunity Commission v. Arabian American Oil Co., 499 U.S. 244, 248 (1991) (presumption against extraterritoriality); 


\section{Sovereign Immunity \& Domestic Officer Suits}

in urging "judicial caution" in the development of ATS causes of action. $^{5}$

\section{CONCLUSION}

For hundreds of years in both Great Britain and the United
States, courts accorded broader immunity in foreign officer suits than in domestic officer suits. There is no indication in any of the relevant statutes that Congress has attempted to override this common law backdrop. There also continue to be good functional reasons for preserving the distinction between domestic and foreign officer suits.

\section{Sis}

Munaf v. Geren, 128 S. Ct. 2207, 2226 (2008) (rule of non-inquiry).

${ }^{50}$ See 542 U.S. at $725,727,728$. 